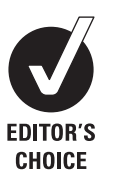

Leiden University Medical Center, Leiden, The Netherlands

${ }^{2}$ Rheumatology Department, Coimbra University Hospital,

Coimbra, Portugal

${ }^{3}$ Rheumatology,

Rheumazentrum Ruhrgebiet

Herne, Ruhr-University Bochum,

Bochum, Germany

${ }^{4}$ Radiology Department, Charité

Medical School, Berlin, Germany

${ }^{5}$ Research and Development,

Centocor Inc., Malvern,

Pennsylvania, USA

${ }^{6}$ Rheumatology Department,

Academic Medical Center,

Amsterdam and Atrium

Medical Center, Heerlen,

The Netherlands

\section{Correspondence to}

Professor Désirée van

der Heijde, Department

of Rheumatology, Leiden

University Medical Center,

P0 Box 9600, 2300 RC Leiden,

The Netherlands;

d.vanderheijde@kpnplanet.nl

Received 19 May 2011

Accepted 11 August 2011

Published Online First

6 October 2011

\title{
MRI inflammation at the vertebral unit only marginally predicts new syndesmophyte formation: a multilevel analysis in patients with ankylosing spondylitis
}

\author{
Désirée van der Heijde, ${ }^{1}$ Pedro Machado, ${ }^{1,2}$ Jürgen Braun, ${ }^{3}$ Kay-Geert A Hermann, ${ }^{4}$ \\ Xenofon Baraliakos, ${ }^{3}$ Benjamin Hsu, ${ }^{5}$ Daniel Baker, ${ }^{5}$ Robert Landewé ${ }^{6}$
}

\begin{abstract}
Objective To investigate the relationship between MRI inflammation at the vertebral unit and the formation and growth of syndesmophytes at the same vertebral unit. Methods An $80 \%$ random sample of the ASSERT database was analysed. MRI were scored using the ankylosing spondylitis (AS) spinal MRI activity score (at baseline, 24 and 102 weeks) and spinal $x$-rays were scored using the modified Stoke AS spine score (at baseline and 102 weeks). Data were analysed at the patient level and the vertebral unit level using a multilevel approach to adjust for within-patient correlation.

Results There was a slightly increased probability of

reduce inflammation as measured on $\mathrm{MRI}^{7} 8$ do not inhibit syndesmophyte formation and growth. ${ }^{9-11}$

Our aim was to investigate the relationship between inflammation on MRI and the formation/ growth of syndesmophytes, both at the level of the vertebral unit and the patient. In this analysis we carefully adjusted for other factors potentially being associated with syndesmophyte formation. Furthermore, and in contrast to analyses in previous reports, ${ }^{12}{ }^{13}$ we considered within-patient correlation as a spurious source of positive correlations, and we undertook detailed multilevel analysis to adjust for such effects.
\end{abstract} developing syndesmophytes in vertebral units with MRI activity, which was maintained after adjustment for within-patient correlation (per vertebral unit level) and treatment, and after further adjustment for potential confounders, resulting in significant $\mathrm{OR}$ ranging from 1.51 to 2.26. Growth of existing syndesmophytes at the vertebral unit level was not associated with MRI activity. At the patient level only a trend for an association was observed.

Conclusion MRI inflammation in a vertebral unit slightly increases the propensity to form a new syndesmophyte in the same vertebral unit, but does not predict the growth of already existing syndesmophytes. Despite this association, the large majority of new syndesmophytes developed in vertebral units without inflammation. The subtle association at the vertebral unit level did not translate into an association at the patient level.

Ankylosing spondylitis (AS) is a chronic inflammatory disease characterised by reversible inflammation and irreversible structural damage of the spine. ${ }^{1} \mathrm{MRI}$ has emerged in recent years as a useful assessment tool because of its ability to detect active inflammatory lesions in the spine..$^{2-5}$

Structural damage in AS is characterised by excessive bone formation, with syndesmophytes as the typical lesion. $\mathrm{x}$-Rays are still considered the gold standard for the assessment of syndesmophytes in AS. ${ }^{1}$

The processes underlying syndesmophyte formation are insufficiently understood. Bone proliferation may reflect a pathologically enhanced repair response of bone ${ }^{16}$ and a causal relationship between MRI inflammation and syndesmophyte formation is hypothesised. However, tumour necrosis factor (TNF) blockers that dramatically

\section{METHODS}

\section{AS patient population}

A random $80 \%$ sample of the AS Study for the Evaluation of Recombinant Infliximab Therapy (ASSERT) cohort was used for this analysis. ${ }^{14}$ ASSERT was a 24-week randomised controlled trial comparing infliximab and placebo in patients with active AS, with an open extension until 102 weeks with all patients treated with infliximab. The details of the ASSERT study have been reported elsewhere. ${ }^{14}$ Data from 1827 to 2070 vertebral units, belonging to 177-182 patients were available for paired analysis (the total number of available vertebral units/patients in each analysis depends on the case definition and reader used per analysis; an additional source of variation in numbers is because sometimes one of the two readers scored a vertebral unit as not evaluable).

\section{MRI assessment}

Images were scored according to the AS spinal MRI activity (ASspiMRI-a) score. ${ }^{15} \mathrm{~A}$ vertebral unit is defined as the region between two virtual lines through the middle of each vertebra, and all 23 vertebral units of the spine (C2-S1) are scored for enhancement ( $T 1$ postgadolinium images) and bone marrow oedema (short-tau inversion recovery images), with a grading system from 0 to 3 , with three more grades (4-6) if, in addition to inflammation, erosions are also visualised (maximum total score 138).

\section{Radiographic assessment}

Lateral views of the cervical and lumbar spine were scored according to the modified Stoke AS spine score (mSASSS). ${ }^{16}$ The mSASSS scores anterior 
Table 1 Two-way analysis to test the association between MRI vertebral unit activity and syndesmophyte formation/growth after 2 years' follow-up*

\begin{tabular}{lllllllll}
\hline & $\begin{array}{l}\text { New syndesmophytes } \\
\text { (R1 or R2) }\end{array}$ & $\begin{array}{l}\text { New syndesmophytes } \\
\text { (R1 and R2) }\end{array}$ & $\begin{array}{l}\text { Growth of syndesmophytes } \\
\text { (R1 or R2) }\end{array}$ & $\begin{array}{l}\text { Growth of syndesmophytes } \\
\text { (R1 and R2) }\end{array}$ \\
\cline { 2 - 9 } & Yes, N (\%) & No, N (\%) & Yes, N (\%) & No, N (\%) & Yes, N (\%) & No, N (\%) & Yes, N (\%) & No, N (\%)
\end{tabular}

MRI reader 1:

Active vertebral unit at $B L$ Inactive vertebral unit at $\mathrm{BL}$ OR $(95 \% \mathrm{Cl})$

MRI reader 2:

Active vertebral unit at BL Inactive vertebral unit at $\mathrm{BL}$ OR $(95 \% \mathrm{Cl})$

MRI reader 1:

Active vertebral unit at BL only Inactive vertebral unit at $\mathrm{BL}$, or active at $B L$ and other TP

OR $(95 \% \mathrm{Cl})$

MRI reader 2:

Active vertebral unit at BL only Inactive vertebral unit at $\mathrm{BL}$, or active at $\mathrm{BL}$ and other TP

OR $(95 \% \mathrm{Cl})$

MRI reader 1:

Active vertebral unit at BL and another TP

Inactive vertebral unit at $\mathrm{BL}$, or active at BL but not at other TP OR (95\% Cl)

MRI reader 2:

Active vertebral unit at $\mathrm{BL}$ and another TP

Inactive vertebral unit at $\mathrm{BL}$, or active at BL but not at other TP OR $(95 \% \mathrm{Cl})$

MRI reader 1:

Active vertebral unit at any TP

Always inactive vertebral unit

OR $(95 \% \mathrm{Cl})$

MRI reader 2:

Active vertebral unit at any TP Always inactive vertebral unit OR (95\% Cl)

MRI reader 1:

Always active vertebral unit

Not-always active vertebral unit OR $(95 \% \mathrm{Cl})$

MRI reader 2:

Always active vertebral unit

Not-always active vertebral unit $\underline{\mathrm{OR}}(95 \% \mathrm{Cl})$

$36(10.9 / 24.2) \quad 295(89.1 / 16.1) \quad 12(3.6 / 27.9) \quad 323(96.4 / 16.2)$

$113(6.8 / 75.8) \quad 1537(93.2 / 83.9) \quad 31(1.8 / 72.1) \quad 1677(98.2 / 83.9) \quad 22(1.3 / 84.6) \quad 1627(98.7 / 83.3)$ 1.66 (1.12 to 2.47)

2.01 (1.02 to 3.96) \begin{tabular}{cccccr}
$36(12.1 / 23.8)$ & $261(87.9 / 14.1)$ & $10(3.3 / 22.7)$ & $294(96.7 / 14.5)$ & $6(2.0 / 22.2)$ & $291(98.0 / 14.7)$ \\
$115(6.7 / 76.2)$ & $1592(93.3 / 85.9)$ & $34(1.9 / 77.3)$ & $1731(98.1 / 85.5)$ & $21(1.2 / 77.8)$ & $1685(98.8 / 85.3)$ \\
$\mathbf{1 . 9 1}(\mathbf{1 . 2 8}$ to 2.84) & \multicolumn{3}{c}{$1.73(0.85$ to 3.54$)$} & $1.65(0.66$ to 4.13$)$
\end{tabular}

$\begin{array}{llllll}27(11.4 / 18.1) & 209(88.6 / 11.4) & 9(3.8 / 20.9) & 229(96.2 / 11.5) & 2(0.8 / 7.7) & 234(99.2 / 12.0)\end{array}$ $122(7.0 / 81.9) \quad 1623(93.0 / 88.6) \quad 34(1.9 / 79.1) \quad 1771(98.1 / 88.6) \quad 24(1.4 / 92.3) \quad 1720(98.6 / 88.0)$

1.72 (1.11 to 2.67$)$

2.05 (0.97 to 4.32)

0.61 (0.14 to 2.61)

$\begin{array}{llllllll}22(11.3 / 14.6) & 173(88.7 / 9.3) & 7(3.5 / 15.9) & 191(96.5 / 9.4) & 4(2.1 / 14.8) & 191(97.9 / 9.7) & 2(1.0 / 28.6) & 196(99.0 / 9.5)\end{array}$ $129(7.1 / 85.4) \quad 1680(92.9 / 90.7) \quad 37(2.0 / 84.1) \quad 1834(98.0 / 90.6) \quad 23(1.3 / 85.2) \quad 1785(98.7 / 90.3) \quad 5(0.3 / 71.4) \quad 1867(99.7 / 90.5)$

1.66 (1.03 to 2.67$)$

$1.82(0.80$ to 4.13$)$

1.63 (0.56 to 4.75$)$

3.81 (0.73 to 19.8$)$

\begin{tabular}{cccccccc}
$9(10.8 / 6.0)$ & $74(89.2 / 4.1)$ & $3(3.5 / 7.0)$ & $82(96.5 / 4.1)$ & $2(2.4 / 7.7)$ & $81(97.6 / 4.2)$ & $0(0.0 / 0.0)$ & $85(100 / 4.2)$ \\
$140(7.4 / 94.0)$ & $1746(92.6 / 95.9)$ & $40(2.1 / 93.0)$ & $1906(97.9 / 95.9)$ & $24(1.3 / 92.3)$ & $1861(98.7 / 95.8)$ & $7(0.4 / 100)$ & $1940(99.6 / 95.8)$ \\
$1.52(0.74$ to 3.09) & \multicolumn{2}{c}{$1.74(0.53$ to 5.75$)$} & $1.92(0.45$ to 8.24$)$ & NA (p=0.580)
\end{tabular}

$14(14.3 / 9.3) \quad 84(85.7 / 4.5) \quad 3(2.9 / 6.8) \quad 99(97.1 / 4.9) \quad 2(2.0 / 7.4) \quad 96(98.0 / 4.9) \quad 0(0.0 / 0.0) \quad 102(100 / 5.0)$

$137(7.2 / 90.7) \quad 1765(92.8 / 95.5) \quad 41(2.1 / 93.2) \quad 1922(97.9 / 95.1) \quad 25(1.3 / 92.6) \quad 1876(98.7 / 95.1) \quad 7(0.4 / 100) \quad 1957(99.6 / 95.0)$

2.15 (1.19 to 3.89$) \quad 1.42$ (0.43 to 4.67$) \quad 1.56$ (0.37 to 6.70$)$

$\begin{array}{llllllll}40(11.2 / 28.6) & 318(88.8 / 18.7) & 12(3.3 / 31.6) & 349(96.7 / 18.8) & 5(1.4 / 21.7) & 352(98.6 / 19.4) & 1(0.3 / 16.7) & 361 \\ (99.7 / 19.1)\end{array}$ $\begin{array}{llllllll}100(6.7 / 71.4) & 1385(93.3 / 81.3) & 26(1.7 / 68.4) & 1511(98.3 / 81.2) & 18(1.2 / 78.3) & 1467(98.8 / 80.6) & 5(0.3 / 83.3) & 1532(99.7 / 80.9)\end{array}$

$1.74(1.18$ to 2.56$) \quad 2.00(1.00$ to 4.00$) \quad 1.16(0.43$ to 3.14$)$

$\begin{array}{llllllll}40(11.9 / 26.8) & 297(88.1 / 16.7) & 10(2.9 / 23.3) & 334(97.1 / 17.2) & 8(2.4 / 29.6) & 329(97.6 / 17.4) & 2(0.6 / 28.6) & 342(99.4 / 17.3)\end{array}$ $109(6.9 / 73.2) \quad 1477(6.9 / 73.2) \quad 33(2.0 / 76.7) \quad 1607(98.0 / 82.8) \quad 19(1.2 / 70.4) \quad 1566(98.8 / 82.6) \quad 5(0.3 / 71.4) \quad 1636(99.7 / 82.7)$ 1.83 (1.24 to 2.68$) \quad 1.46(0.71$ to 2.99$) \quad 2.00(0.87$ to 4.62$)$

$\begin{array}{llllllll}0(0.0 / 0.0) & 8(100 / 0.5) & 0(0.0 / 0.0) & 8(100 / 0.4) & 0(0.0 / 0.0) & 8(100 / 0.4) & 0(0.0 / 0.0) & 8(100 / 0.4)\end{array}$ NA $(p=0.414) \quad$ NA $(p=0.684) \quad$ NA $(p=0.749)$ $\mathrm{NA}(\mathrm{p}=0.873)$

$\begin{array}{llllllll}0(0.0 / 0.0) & 6(100 / 0.3) & 0(0.0 / 0.0) & 6(100 / 0.3) & 0(0.0 / 0.0) & 6(100 / 0.3) & 0(0.0 / 0.0) & 6(100 / 0.3)\end{array}$ $149(7.8 / 100) \quad 1763(92.2 / 99.7) \quad 43(2.2 / 100) \quad 1930(97.8 / 99.7) \quad 27(1.4 / 100) \quad 1884(98.6 / 99.7) \quad 7(0.4 / 100) \quad 1967(99.6 / 99.7)$ NA $(p=0.476) \quad N A(p=0.715)$

*In the table cells, the first percentage uses MRI activity as denominator, while the second percentage (in italic) uses syndesmophyte formation/growth as denominator. Statistically significant OR at the $5 \%$ level are highlighted in bold. For cases in which the cell count is 0 , the OR could not be calculated and the $p$ value of the Pearson $\chi^{2}$ result is provided.

BL, baseline; NA, not applicable; R1/R2, reader 1/reader 2; TP, time point.

vertebral corners of the cervical and lumbar spine at 24 levels (C2-T1 and T12-S1, corresponding to 12 vertebral units). It includes squaring, erosions, sclerosis (score 1 for one or more of these features present), syndesmophyte (score 2 ) and bridging (score 3). Therefore, the total mSASSS ranges from 0 (completely normal) to 72 (complete bridging).

\section{Reading of radiographs and MRI images}

MRI and spinal radiographs were scored by four qualified and well-trained readers (two for the radiographs and two for the MRI images), who were blinded to the patient's identity, time order and treatment. The two-way random model, absolute agreement type and average measures intraclass correlation coefficients for the MRI scores were 0.84 (baseline), 0.64 (24 weeks), 0.57 (102 weeks), 0.78 (24 weeks change) and 0.83 (102 weeks change). The intraclass correlation coefficients for the x-ray scores were 0.96 (baseline), 0.97 (102 weeks) and 0.86 (102 weeks change).

\section{Case definition}

Five case definitions were used for MRI inflammation (activity) at the vertebral unit:

1. Active vertebral unit at baseline, irrespective of inflammation status at other time points;

2. Active vertebral unit at baseline only;

3. Active vertebral unit at baseline and another time point; 
Table 2 GEE results (OR; 95\% Cl; $p$ values) for the outcome syndesmophyte formation according to reader 1 or reader 2, with MRI vertebral unit inflammation as determinant, and with adjustment for within-patient correlation by vertebral unit level and MRI reader (first line), for individual potential confounders (second to 11 th line) and for all significant confounders (last two lines)*

\begin{tabular}{|c|c|c|c|c|c|c|c|c|}
\hline Adjustment factor & $\begin{array}{l}\text { Active vertebral } \\
\text { unit at baseline }\end{array}$ & $\begin{array}{l}\text { Adjustment } \\
\text { factor }\end{array}$ & $\begin{array}{l}\text { Active vertebral } \\
\text { unit at baseline } \\
\text { only }\end{array}$ & $\begin{array}{l}\text { Adjustment } \\
\text { factor }\end{array}$ & $\begin{array}{l}\text { Active vertebral } \\
\text { unit at baseline and } \\
\text { another time point }\end{array}$ & $\begin{array}{l}\text { Adjustment } \\
\text { factor }\end{array}$ & $\begin{array}{l}\text { Active vertebral } \\
\text { unit at any time } \\
\text { point }\end{array}$ & $\begin{array}{l}\text { Adjustment } \\
\text { factor }\end{array}$ \\
\hline $\begin{array}{l}\text { Within-patient } \\
\text { correlation }\end{array}$ & $\begin{array}{l}1.64(1.12 \text { to } 2.41) \\
p=0.012\end{array}$ & NA & $\begin{array}{l}1.50(0.95 \text { to } 2.35) \\
p=0.079\end{array}$ & NA & $\begin{array}{l}1.69(0.90 \text { to } 3.17) \\
p=0.105\end{array}$ & NA & $\begin{array}{l}1.72(1.20 \text { to } 2.44) \\
p=0.003\end{array}$ & NA \\
\hline Gender & $\begin{array}{l}1.57(1.08 \text { to } 2.28) \\
p=0.018\end{array}$ & $\begin{array}{l}2.79(1.45 \text { to } \\
5.40) p=0.002\end{array}$ & $\begin{array}{l}1.44(0.94 \text { to } 2.22) \\
\mathrm{p}=0.098\end{array}$ & $\begin{array}{l}2.81(1.45 \text { to } \\
5.44) p=0.002\end{array}$ & $\begin{array}{l}1.66(0.89 \text { to } 3.09) \\
p=0.109\end{array}$ & $\begin{array}{l}2.89(1.48 \text { to } \\
5.67) p=0.002\end{array}$ & $\begin{array}{l}1.64(1.16 \text { to } 2.33) \\
p=0.005\end{array}$ & $\begin{array}{l}2.73(1.41 \text { to } \\
5.28) p=0.003\end{array}$ \\
\hline HLA-B27 & $\begin{array}{l}1.64(1.12 \text { to } 2.41) \\
p=0.011\end{array}$ & NS & $\begin{array}{l}1.50(0.95 \text { to } 2.36) \\
p=0.079\end{array}$ & NS & $\begin{array}{l}1.69(0.90 \text { to } 3.17) \\
p=0.103\end{array}$ & NS & $\begin{array}{l}1.72(1.21 \text { to } 2.46) \\
p=0.003\end{array}$ & NS \\
\hline Disease duration & $\begin{array}{l}1.64(1.11 \text { to } 2.40) \\
p=0.012\end{array}$ & NS & $\begin{array}{l}1.49(0.95 \text { to } 2.35) \\
p=0.083\end{array}$ & NS & $\begin{array}{l}1.68(0.90 \text { to } 3.15) \\
p=0.106\end{array}$ & NS & $\begin{array}{l}1.71(1.20 \text { to } 2.44) \\
p=0.003\end{array}$ & NS \\
\hline BASDAI at baseline & $\begin{array}{l}1.67(1.13 \text { to } 2.47) \\
p=0.010\end{array}$ & NS & $\begin{array}{l}1.56(0.98 \text { to } 2.46) \\
p=0.059\end{array}$ & NS & $\begin{array}{l}1.66(0.89 \text { to } 3.09) \\
p=0.111\end{array}$ & NS & $\begin{array}{l}1.74(1.21 \text { to } 2.49) \\
p=0.003\end{array}$ & NS \\
\hline BASDAI AUC & $\begin{array}{l}1.68(1.14 \text { to } 2.48) \\
p=0.009\end{array}$ & $\begin{array}{l}0.999(0.998 \text { to } \\
1.000) p=0.046\end{array}$ & $\begin{array}{l}1.56(0.98 \text { to } 2.47) \\
p=0.061\end{array}$ & $\begin{array}{l}0.999(0.998 \text { to } \\
1.000) p=0.049\end{array}$ & $\begin{array}{l}1.67(0.89 \text { to } 3.13) \\
p=0.109\end{array}$ & NS & $\begin{array}{l}1.73(1.21 \text { to } 2.47) \\
p=0.003\end{array}$ & $\begin{array}{l}0.999(0.998 \\
\text { to } 1.000) \\
p=0.021\end{array}$ \\
\hline $\begin{array}{l}\text { Total mSASSS at } \\
\text { baseline }>5\end{array}$ & $\begin{array}{l}1.55(1.06 \text { to } 2.25) \\
p=0.023\end{array}$ & $\begin{array}{l}2.59(1.29 \text { to } \\
5.20) p=0.007\end{array}$ & $\begin{array}{l}1.43(0.92 \text { to } 2.22) \\
p=0.115\end{array}$ & $\begin{array}{l}2.63(1.31 \text { to } \\
5.29) p=0.007\end{array}$ & $\begin{array}{l}1.60(0.86 \text { to } 2.97) \\
p=0.136\end{array}$ & $\begin{array}{l}2.63(1.30 \text { to } \\
5.29) p=0.007\end{array}$ & $\begin{array}{l}1.63(1.15 \text { to } 2.31) \\
p=0.006\end{array}$ & $\begin{array}{l}2.40(1.20 \text { to } \\
4.80) p=0.014\end{array}$ \\
\hline $\begin{array}{l}\text { Syndesmophytes or } \\
\text { bridging at baseline }\end{array}$ & $\begin{array}{l}1.57(1.07 \text { to } 2.30) \\
p=0.021\end{array}$ & $\begin{array}{l}2.58(1.36 \text { to } \\
4.87) p=0.004\end{array}$ & $\begin{array}{l}1.44(0.92 \text { to } 2.24) \\
p=0.109\end{array}$ & $\begin{array}{l}2.64(1.40 \text { to } \\
4.98) p=0.003\end{array}$ & $\begin{array}{l}1.64(0.87 \text { to } 3.08) \\
p=0.124\end{array}$ & $\begin{array}{l}2.67(1.41 \text { to } \\
5.05) p=0.003\end{array}$ & $\begin{array}{l}1.62(1.14 \text { to } 2.32) \\
p=0.008\end{array}$ & $\begin{array}{l}2.39(1.27 \text { to } \\
4.50) p=0.007\end{array}$ \\
\hline $\begin{array}{l}\text { Adjustment for all } \\
\text { significant variables }\end{array}$ & $\begin{array}{l}1.51(1.05 \text { to } 2.19) \\
\mathrm{p}=0.028\end{array}$ & NA & $\begin{array}{l}1.43(0.92 \text { to } 2.20) \\
p=0.109\end{array}$ & NA & $\begin{array}{l}1.57(0.85 \text { to } 2.89) \\
p=0.150\end{array}$ & NA & $\begin{array}{l}1.55(1.01 \text { to } 2.19) \\
p=0.012\end{array}$ & NA \\
\hline $\begin{array}{l}\text { Adjustment for all } \\
\text { significant variables }\end{array}$ & $\begin{array}{l}1.56(1.07 \text { to } 2.27) \\
p=0.020\end{array}$ & NA & $\begin{array}{l}1.46(0.95 \text { to } 2.26) \\
p=0.088\end{array}$ & NA & $\begin{array}{l}1.62(0.87 \text { to } 3.02) \\
p=0.130\end{array}$ & NA & $\begin{array}{l}1.57(1.10 \text { to } 2.24) \\
p=0.012\end{array}$ & NA \\
\hline
\end{tabular}

Statistically significant $\mathrm{OR}$ after adjustment for within-patient correlation (first line) and after adjustment for all significant confounders (last two line) are highlighted in bold.

${ }^{*}$ All models adjusted for treatment effect (non-significant) and for within-patient correlation (by vertebral unit level and MRI reader).

${ }^{\dagger}$ Adjusted for 'total mSASSS at baseline $>5^{\prime}$ '.

${ }^{\ddagger}$ Adjusted for presence of 'syndesmophytes or bridging at baseline' (at the patient level, according to both readers).

AUC, area under the curve; BASDAI, Bath ankylosing spondylitis disease activity index; CRP, C-reactive protein; GEE, generalised estimating equation; HLA, human leucocyte antigen; mSASSS, modified Stoke AS spine score; NA, not applicable; NS, non-significant.

4. Active vertebral unit at any time point;

5. Active vertebral unit at all time points.

The presence of activity/inflammation in a vertebral unit was defined as an MRI score greater than 0 in that vertebral unit.

Two case definitions were used for syndesmophyte formation/ growth:

1. A definition based on sensitivity: a case was defined as positive if at least one of the readers reported progression;

2. A definition based on specificity: a case was defined as positive only if both readers reported progression (absolute agreement).

Syndesmophyte formation at a vertebral unit was defined as an increase of a score of 0 or 1 to a score of 2 or 3 at any of the two vertebral corners of the same vertebral unit. Syndesmophyte growth at a vertebral unit was defined as an increase of a score of 2 to 3 at the vertebral corners of the vertebral unit. The various case definitions for MRI and syndesmophyte formation/growth resulted in 20 scenarios for each MRI reader (table 1).

For the total mSASSS and ASspiMRI-a score, the mean of both readers' scores was used in the analysis.

\section{Statistical analysis}

Statistical analyses were performed using SPSS 18. Data were analysed at the vertebral unit level in the 12 vertebral units that are assessed by both scoring systems and at the patient level using total ASspiMRI-a and mSASSS scores of these 12 vertebral units.

Cross-tabulation statistics and measures of association (OR and $95 \% \mathrm{CI}$ ) were first computed using two-way tables to test the association between MRI vertebral unit inflammation and syndesmophyte formation/growth according to all the abovespecified definitions.

Statistically significant associations and associations where a trend was observed were re-tested using generalised estimating equation (GEE) analysis, adjusting for within-patient correlation (by vertebral unit level and MRI reader, ie, adjusting for the dependence of observations arising from multiple measurements in different vertebral units of the same patient and adjusting for the MRI reader as another source of dependency of results), treatment and other factors known or expected to be associated with syndesmophyte formation/growth, namely clinical disease activity (assessed by the Bath ankylosing spondylitis disease activity index), ${ }^{17} \mathrm{C}$-reactive protein, gender, age, disease duration, human leucocyte antigen (HLA)-B27 status and presence of syndesmophytes/bridging at baseline.

\section{RESULTS \\ Relationship between MRI activity at the vertebral unit level and formation/growth of syndesmophytes}

Excluding the 'always active' case definition, there was a preference to develop syndesmophytes in vertebral units with compared with vertebral units without MRI activity for both syndesmophyte definitions and for both MRI readers (table 1, $\mathrm{OR}$ ranging from 1.42 to 2.15 , statistically significant in the majority of case definitions). The growth of existing syndesmophytes at the vertebral unit level was not associated with MRI activity (table 1,OR ranging from 0.61 to 3.81 , always non- 
Table 3 GEE results (OR; $95 \% \mathrm{Cl}$; $\mathrm{p}$ values) for the outcome syndesmophyte formation according to reader 1 and reader 2, with MRI vertebral unit inflammation as determinant, and with adjustment for within-patient correlation by vertebral unit level and MRI reader (first line), for individual potential confounders (second to 11 th line) and for all significant confounders (last line) ${ }^{*}$

\begin{tabular}{|c|c|c|c|c|c|c|c|c|}
\hline $\begin{array}{l}\text { Adjustment } \\
\text { factor }\end{array}$ & $\begin{array}{l}\text { Active vertebral } \\
\text { unit at baseline }\end{array}$ & $\begin{array}{l}\text { Adjustment } \\
\text { factor }\end{array}$ & $\begin{array}{l}\text { Active vertebral } \\
\text { unit at baseline } \\
\text { only }\end{array}$ & $\begin{array}{l}\text { Adjustment } \\
\text { factor }\end{array}$ & $\begin{array}{l}\text { Active vertebral } \\
\text { unit at baseline and } \\
\text { another time point }\end{array}$ & $\begin{array}{l}\text { Adjustment } \\
\text { factor }\end{array}$ & $\begin{array}{l}\text { Active vertebral } \\
\text { unit at any time } \\
\text { point }\end{array}$ & $\begin{array}{l}\text { Adjustment } \\
\text { factor }\end{array}$ \\
\hline $\begin{array}{l}\text { Within-patient } \\
\text { correlation }\end{array}$ & $\begin{array}{l}1.85(1.01 \text { to } 3.41) \\
p=0.048\end{array}$ & NA & $\begin{array}{l}2.06(1.04 \text { to } 4.05) \\
p=0.037\end{array}$ & NA & $\begin{array}{l}1.11(0.46 \text { to } 2.67) \\
p=0.813\end{array}$ & NA & $\begin{array}{l}1.77(0.95 \text { to } 3.27) \\
p=0.070\end{array}$ & NA \\
\hline Gender & $\begin{array}{l}1.75(0.96 \text { to } 3.20) \\
p=0.067\end{array}$ & $\begin{array}{l}3.70(1.01 \text { to } \\
13.48) p=0.048\end{array}$ & $\begin{array}{l}1.93(0.99 \text { to } 3.75) \\
p=0.053\end{array}$ & NS & $\begin{array}{l}1.14(0.48 \text { to } 2.70) \\
p=0.771\end{array}$ & $\begin{array}{l}4.00 \text { (1.18 to } \\
13.61) p=0.026\end{array}$ & $\begin{array}{l}1.67(0.91 \text { to } 3.08) \\
p=0.098\end{array}$ & NS \\
\hline HLA-B27 & $\begin{array}{l}1.91(1.05 \text { to } 3.47) \\
p=0.034\end{array}$ & $\begin{array}{l}3.38(1.14 \text { to } \\
9.99) p=0.028\end{array}$ & $\begin{array}{l}2.11(1.07 \text { to } 4.14) \\
p=0.031\end{array}$ & $\begin{array}{l}3.46(1.16 \text { to } \\
10.27) p=0.026\end{array}$ & $\begin{array}{l}1.16(0.51 \text { to } 2.66) \\
p=0.726\end{array}$ & $\begin{array}{l}3.18(1.08 \text { to } \\
9.42) p=0.036\end{array}$ & $\begin{array}{l}1.85(1.01 \text { to } 3.38) \\
p=0.046\end{array}$ & $\begin{array}{l}3.77(1.27 \text { to } \\
11.18) p=0.017\end{array}$ \\
\hline Age & $\begin{array}{l}1.85(0.98 \text { to } 3.52) \\
p=0.060\end{array}$ & NS & $\begin{array}{l}2.08(1.02 \text { to } 4.23) \\
p=0.044\end{array}$ & NS & $\begin{array}{l}1.11(0.43 \text { to } 2.90) \\
p=0.829\end{array}$ & NS & $\begin{array}{l}1.76(0.92 \text { to } 3.34) \\
p=0.086\end{array}$ & NS \\
\hline Disease duration & $\begin{array}{l}1.85(0.99 \text { to } 3.43) \\
p=0.052\end{array}$ & NS & $\begin{array}{l}2.06(1.04 \text { to } 4.10) \\
p=0.040\end{array}$ & NS & $\begin{array}{l}1.10(0.45 \text { to } 2.68) \\
p=0.836\end{array}$ & NS & $\begin{array}{l}1.77(0.95 \text { to } 3.28) \\
p=0.073\end{array}$ & NS \\
\hline BASDAl at baseline & $\begin{array}{l}1.90(0.96 \text { to } 3.76) \\
p=0.065\end{array}$ & $\begin{array}{l}0.63(0.44 \text { to } \\
0.89) \mathrm{p}=0.010\end{array}$ & $\begin{array}{l}2.22(1.06 \text { to } 4.64) \\
p=0.034\end{array}$ & $\begin{array}{l}0.63(0.45 \text { to } \\
0.88) p=0.007\end{array}$ & $\begin{array}{l}1.09(0.40 \text { to } 2.95) \\
p=0.866\end{array}$ & $\begin{array}{l}0.64(0.45 \text { to } \\
0.90) p=0.010\end{array}$ & $\begin{array}{l}1.74(0.88 \text { to } 3.45) \\
p=0.114\end{array}$ & $\begin{array}{l}0.60(0.41 \text { to } \\
0.86) p=0.006\end{array}$ \\
\hline BASDAI AUC & $\begin{array}{l}1.91(0.99 \text { to } 3.65) \\
p=0.052\end{array}$ & NS & $\begin{array}{l}2.20(1.06 \text { to } 4.58) \\
p=0.034\end{array}$ & $\begin{array}{l}0.998(0.997 \text { to } \\
1.000) p=0.046\end{array}$ & $\begin{array}{l}1.07(0.43 \text { to } 2.67) \\
p=0.879\end{array}$ & NS & $\begin{array}{l}1.76(0.93 \text { to } 3.35) \\
p=0.083\end{array}$ & NS \\
\hline CRP at baseline & $\begin{array}{l}1.73(0.91 \text { to } 3.33) \\
p=0.097\end{array}$ & NS & $\begin{array}{l}1.82(0.90 \text { to } 3.69) \\
p=0.097\end{array}$ & NS & $\begin{array}{l}1.27(0.55 \text { to } 2.91) \\
p=0.573\end{array}$ & NS & $\begin{array}{l}1.62(0.84 \text { to } 3.13) \\
p=0.147\end{array}$ & NS \\
\hline CRP AUC & $\begin{array}{l}1.76(0.95 \text { to } 3.27) \\
p=0.072\end{array}$ & NS & $\begin{array}{l}1.83(0.93 \text { to } 3.58) \\
p=0.079\end{array}$ & NS & $\begin{array}{l}1.30(0.63 \text { to } 2.70) \\
p=0.475\end{array}$ & NS & $\begin{array}{l}1.69(0.91 \text { to } 3.13) \\
p=0.097\end{array}$ & NS \\
\hline $\begin{array}{l}\text { Total mSASSS at } \\
\text { baseline }>5\end{array}$ & $\begin{array}{l}1.72(0.91 \text { to } 3.24) \\
p=0.094\end{array}$ & NS & $\begin{array}{l}1.95(0.95 \text { to } 4.01) \\
p=0.068\end{array}$ & NS & $\begin{array}{l}1.02(0.41 \text { to } 2.57) \\
p=0.963\end{array}$ & NS & $\begin{array}{l}1.66(0.87 \text { to } 3.14) \\
p=0.121\end{array}$ & NS \\
\hline $\begin{array}{l}\text { Syndesmophytes or } \\
\text { bridging at baseline }\end{array}$ & $\begin{array}{l}1.67(0.88 \text { to } 3.18) \\
p=0.116\end{array}$ & NS & $\begin{array}{l}1.91(0.92 \text { to } 3.96) \\
p=0.084\end{array}$ & NS & $\begin{array}{l}1.00(0.38 \text { to } 2.63) \\
p=0.995\end{array}$ & NS & $\begin{array}{l}1.62(0.84 \text { to } 3.10) \\
p=0.147\end{array}$ & NS \\
\hline $\begin{array}{l}\text { Adjustment for all } \\
\text { significant variables }\end{array}$ & $\begin{array}{l}1.89(0.98 \text { to } 3.65) \\
p=0.056\end{array}$ & NA & $\begin{array}{l}2.26(1.08 \text { to } 4.74) \\
p=0.031\end{array}$ & NA & $\begin{array}{l}1.22(0.47 \text { to } 3.15) \\
p=0.678\end{array}$ & NA & $\begin{array}{l}1.43(0.59 \text { to } 3.49) \\
p=0.426\end{array}$ & NA \\
\hline
\end{tabular}

Statistically significant OR after adjustment for within-patient correlation (first line) and after adjustment for all significant confounders (last line) are highlighted in bold.

${ }^{*}$ All models adjusted for treatment effect (non-significant) and for within-patient correlation (by vertebral unit level and MRI reader).

AUC, area under the curve; BASDAI, Bath ankylosing spondylitis disease activity index; CRP, C-reactive protein; GEE, generalised estimating equation; HLA, human leucocyte antigen; mSASSS, modified Stoke AS spine score; NA, not applicable; NS, non-significant.

significant). Vertebral units with inflammation at all time points ('always active') did not develop syndesmophytes and did not show growth of existing syndesmophytes (table 1).

From the syndesmophyte perspective, depending on the syndesmophyte case definition, the MRI reader and the MRI case definition (and excluding the 'always active' case definition), 6-32\% of new syndesmophytes developed in vertebral units with active inflammation and 68-94\% of new syndesmophytes developed in vertebral units without active inflammation. Similarly, 0-30\% of the syndesmophytes that showed growth did so in active vertebral units and 70-100\% of the syndesmophytes that showed growth did so in vertebral units without inflammation (table 1).

\section{GEE analysis at the vertebral unit level and at the patient level}

The increased probability of developing new syndesmophytes in active vertebral units was confirmed by GEE analysis, and maintained after adjustment for within-patient correlation (by vertebral unit level and MRI reader), treatment and further adjustment for potential confounders: OR 1.43-1.57, for syndesmophyte formation according to readers 1 or 2 (table 2), and OR 1.22-2.26 for syndesmophyte formation according to readers 1 and 2 (table 3 ). However, results were not always statistically significant, and for some case definitions only a trend was observed (tables 2 and 3).

Gender, disease activity, baseline total mSASSS ( $>5$ units), the presence of syndesmophytes or bridging at baseline and HLAB27 were shown to be independent contributors to syndesmophyte formation (tables 2 and 3).

At the patient level, in GEE analysis (by MRI reader and with adjustment for treatment), an increase in the mSASSS from baseline to 2 years was not associated with a higher baseline MRI activity score (regression coefficient (B) $0.109 ; 95 \%$ CI -0.132 to 0.350 ; $\mathrm{p}=0.375$ ) or time-integrated MRI activity score (B 0.002; $95 \% \mathrm{CI}$
-0.02 to $0.05 ; p=0.337)$. When variables were dichotomised at the patient level - syndesmophyte formation (yes/no) used as dependent variable, and baseline MRI activity or time-integrated MRI activity score (positive/negative) used as independent variablethere was still no association; however, a trend was observed:

1. Syndesmophyte formation according to readers 1 or 2 : OR 1.66; $95 \%$ CI 0.97 to 2.85 ; $\mathrm{p}=0.067$ (for positive MRI activity at baseline) and OR 1.43; 95\% CI 0.82 to 2.51 ; $\mathrm{p}=0.210$ (for positive time-integrated MRI activity).

2. Syndesmophyte formation according to readers 1 and 2: OR 1.63; $95 \%$ CI 0.82 to $3.22 ; p=0.163$ (for positive MRI activity at baseline) and OR 1.64; 95\% CI 0.83 to 3.25 ; $\mathrm{p}=0.154$ (for positive time-integrated MRI activity).

\section{DISCUSSION}

MRI inflammation in a vertebral unit slightly increases the likelihood of finding a new syndesmophyte in the same vertebral unit 2 years later, but does not predict the growth of already existing syndesmophytes. The majority of syndesmophytes developed in vertebral units without any sign of inflammation on MRI, suggesting that the relationship between MRI inflammation and syndesmophyte formation is not straightforward. For some of the case definitions, this association did not reach statistical significance. The subtle association between MRI activity and new syndesmophytes at the vertebral unit level did not translate into an association at the patient level; however, a trend was also observed.

Two other studies have shown a statistical association between inflammation on MRI of individual vertebral units and the subsequent development of a new syndesmophyte at the same level 2 years later. ${ }^{12} 13$ The strength of association was slightly higher in those studies $(O R \approx 3$ and $O R \approx 5$, respectively) as compared to our 
study $(\mathrm{OR} \approx 1.5-2)$, but also in those studies there were far more new syndesmophytes in non-inflamed vertebral units compared with inflamed vertebral units. Apart from that, the numbers of patients were far lower $\left(n=39,,^{12} n=29\right.$ and $n=41,{ }^{13}$ respectively) and none of them adjusted for within-patient correlation or for potential confounders. Furthermore, we looked at the entire vertebral unit, while the other studies ${ }^{12} 13$ focused on the vertebral edge, but the consequence of this is not known. While Baraliakos et al ${ }^{12}$ only used one MRI reader and Maksymowych et a ${ }^{13}$ only looked at MRI concordant data, our study looked at data from both MRI readers independently.

The subtle association between MRI activity and new syndesmophytes is in conflict with the absence of an effect of TNF blockers on structural damage. ${ }^{9-11}$ One possible explanation to reconcile these two discrepant observations is that syndesmophyte formation is a post-inflammatory repair reaction that may only be inhibited if a TNF blocker is started early, before inflammation gives way to repair. This theory implies a switch from inflammation to repair, which is poorly understood. It has been proposed that persisting inflammation in the context of synovitis (with rheumatoid arthritis as the prototype disease) is dominated by destructive bone-erosive processes (mediated by RANKL, Dkk-1 and sclerostin) and suppression of repair. If inflammation is not chronic but fluctuating (as postulated in AS), repair processes may be switched on, resulting in an anabolic response driven by prostaglandins, Wnt and bone morphogenetic proteins. ${ }^{6}{ }^{18}$ In such a scenario early treatment initiation (before the switch) may prevent the anabolic response that eventually leads to syndesmophyte formation. It is hypothesised that focal fat infiltration at the vertebral corner, which occurs after inflammation of that site, is one of the early signs of repair. In a recent study, the presence of focal fat lesions at a vertebral corner was associated with the development of a syndesmophyte at the same site 2 years later. ${ }^{19}$ Recent studies in rat arthritis models suggest that bony spur formation is a response to injury mechanism of the joint, which is turned on rapidly during initial joint damage, ${ }^{20}$ an observation that also favours the concept that rapid control of inflammation in the early phase of disease could prevent structural damage. However, other authors have suggested that the triggering of new tissue formation may be completely or partly independent of inflammation. ${ }^{21}$

It was recently postulated that syndesmophytes were more likely to develop at those corners in which inflammation resolved than at those where inflammation persisted. ${ }^{13}{ }^{22}$ None of the vertebral units with persistent inflammation ("active at all time points') in our study developed new syndesmophytes, but the numbers were small and inconclusive. The fact that this is a population treated with anti-TNF, a very effective drug in reducing MRI inflammation, explains the low number of vertebral units without persistent inflammation. It would be of interest to expand our analyses to daily practice cohorts with broader profiles of MRI inflammation over time. It would also be of interest to study an early disease population, in which the interplay between inflammatory and bone formation pathways may be different. Furthermore, as syndesmophytes grow slowly, longer study periods would help to clarify the magnitude of the effect of inflammation in predicting bone formation.

In summary, we have shown that MRI inflammation at the vertebral unit only marginally predicts new syndesmophyte formation in that unit. If inflammation is indeed the principal trigger of repair responses, a strong case can be made for early and aggressive anti-inflammatory treatment. Conversely, if inflammation and repair are independent pathways triggered by common factors, new therapies targeting the pathologically enhanced repair response need to be developed.
Funding PM was supported by the Fundação para a Ciência e a Tecnologia (FCT) grant SFRH/BD/62329/2009.

\section{Competing interests None.}

Ethics approval Ethics committee approval was secured for the ASSERT trial. This study is an investigator-preformed subanalysis of the ASSERT cohort.

Provenance and peer review Not commissioned; externally peer reviewed.

\section{REFERENCES}

1. Landewé $\mathbf{R}$, van der Heijde D. A systematic comparison of rheumatoid arthritis and ankylosing spondylitis: structural outcomes. Clin Exp Rheumatol 2009; 27(4 Suppl 55):S102-7.

2. Braun J, Bollow M, Eggens U, et al. Use of dynamic magnetic resonance imaging with fast imaging in the detection of early and advanced sacroiliitis in spondylarthropathy patients. Arthritis Rheum 1994;37:1039-45.

3. Bollow M, Enzweiler C, Taupitz M, et al. Use of contrast enhanced magnetic resonance imaging to detect spinal inflammation in patients with spondyloarthritides. Clin Exp Rheumatol 2002;20(6 Suppl 28):S167-74

4. Hermann KG, Althoff CE, Schneider U, et al. Spinal changes in patients with spondyloarthritis: comparison of MR imaging and radiographic appearances. Radiographics 2005;25:559-69; discussion 569-70.

5. Hermann KG, Landewé RB, Braun J, et al. Magnetic resonance imaging of inflammatory lesions in the spine in ankylosing spondylitis clinical trials: is paramagnetic contrast medium necessary? J Rheumato/ 2005;32:2056-60.

6. Schett G, Rudwaleit M. Can we stop progression of ankylosing spondylitis? Best Pract Res Clin Rheumatol 2010;24:363-71.

7. Braun J, Landewé $\mathrm{R}$, Hermann KG, et al. Major reduction in spinal inflammation in patients with ankylosing spondylitis after treatment with infliximab: results of a multicenter, randomized, double-blind, placebo-controlled magnetic resonance imaging study. Arthritis Rheum 2006;54:1646-52.

8. Baraliakos $\mathbf{X}$, Davis J, Tsuji W, et al. Magnetic resonance imaging examinations of the spine in patients with ankylosing spondylitis before and after therapy with the tumor necrosis factor alpha receptor fusion protein etanercept. Arthritis Rheum 2005; 52:1216-23.

9. van der Heijde $\mathbf{D}$, Landewé $\mathrm{R}$, Einstein $\mathrm{S}$, et al. Radiographic progression of ankylosing spondylitis after up to two years of treatment with etanercept. Arthritis Rheum 2008;58:1324-31.

10. van der Heijde D, Salonen D, Weissman BN, et al. Assessment of radiographic progression in the spines of patients with ankylosing spondylitis treated with adalimumab for up to 2 years. Arthritis Res Ther 2009;11:R127.

11. van der Heijde D, Landewé $R$, Baraliakos $X$, et al. Radiographic findings following two years of infliximab therapy in patients with ankylosing spondylitis. Arthritis Rheum 2008;58:3063-70.

12. Baraliakos $\mathbf{X}$, Listing J, Rudwaleit $\mathrm{M}$, et al. The relationship between inflammation and new bone formation in patients with ankylosing spondylitis. Arthritis Res Ther 2008;10:R104.

13. Maksymowych WP, Chiowchanwisawakit P, Clare T, et al. Inflammatory lesions of the spine on magnetic resonance imaging predict the development of new syndesmophytes in ankylosing spondylitis: evidence of a relationship between inflammation and new bone formation. Arthritis Rheum 2009;60:93-102.

14. van der Heijde D, Dijkmans B, Geusens P, et al. Efficacy and safety of infliximab in patients with ankylosing spondylitis: results of a randomized, placebo-controlled trial (ASSERT). Arthritis Rheum 2005;52:582-91.

15. Braun J, Baraliakos X, Golder W, et al. Magnetic resonance imaging examinations of the spine in patients with ankylosing spondylitis, before and after successful therapy with infliximab: evaluation of a new scoring system. Arthritis Rheum 2003;48:1126-36

16. Creemers MC, Franssen MJ, van't Hof MA, et al. Assessment of outcome in ankylosing spondylitis: an extended radiographic scoring system. Ann Rheum Dis 2005; 64:127-9.

17. Garrett S, Jenkinson T, Kennedy LG, et al. A new approach to defining disease status in ankylosing spondylitis: the Bath Ankylosing Spondylitis Disease Activity Index. J Rheumatol 1994;21:2286-91.

18. Sieper J, Appel H, Braun J, et al. Critical appraisal of assessment of structural damage in ankylosing spondylitis: implications for treatment outcomes. Arthritis Rheum 2008;58:649-56.

19. Chiowchanwisawakit $\mathbf{P}$, Lambert RG, Conner-Spady B, et al. Focal fat lesions at vertebral corners on magnetic resonance imaging predict the development of new syndesmophytes in ankylosing spondylitis. Arthritis Rheum 2011;63:2215-25.

20. Schett G, Stolina M, Dwyer D, et al. Tumor necrosis factor alpha and RANKL blockade cannot halt bony spur formation in experimental inflammatory arthritis. Arthritis Rheum 2009;60:2644-54

21. Lories RJ, Luyten FP, de Vlam K. Progress in spondylarthritis. Mechanisms of new bone formation in spondyloarthritis. Arthritis Res Ther 2009;11:221.

22. Pedersen SJ, Chiowchanwisawakit P, Lambert RG, et al. Resolution of inflammation following treatment of ankylosing spondylitis is associated with new bone formation. J Rheumatol 2011;38:1349-54. 